\title{
KOLME VUOSIKYMMENTÄ PAKOLAISTEN VASTAANOTTOA - Kati Turtiaisen haAstattelu
}

\author{
Johanna Hiitola: YTT, dosentti, yliopistonlehtori, sukupuolentutkimus, Oulun yliopisto \\ Niina Rantamäki: YTM, projektitutkija, sosiaalityö, Kokkeolan yliopistokeskus Chydenius \\ johanna.biitola@oulu.fi;niina.rantamaki@chydenius.fi \\ Janus vol. 28 (3) 2020, 290-298
}

Kati Turtiainen aloitti pakolaistyössä 1980-luvun lopulla, kun Suomessa ryhdyttiin ottamaan vastaan ensimmäisiä kiintiöpakolaisia. Tämän jälkeen hänen koko uransa on keskittynyt pakolaisuuden ja maahanmuuton kysymyksiin. Hän on työskennellyt maahanmuuttotyöntekijänä diakoniatyössä, johtajana Jyväskylän maahanmuuttajapalveluissa ja viimeisimpänä sosiaalityön yliopistonlehtorina Kokkolan yliopistokeskuksessa. Tässä haastattelussa Turtiainen reflektoi pakolaisten vastaanoton ja pakkomuuton kysymyksiä kuluneiden kolmen vuosikymmenen ajalta. Kati Turtiainen täytti 60 vuotta 11.8.2020, ja tämä haastattelu juhlistaa hänen uransa vaiheita. Haastattelijana toimii sukupuolentutkimuksen yliopistonlehtori Johanna Hiitola Oulun yliopistosta.

Kysymys siitä, kunnioittavatko lainsäädäntö ja viranomaiskäytännöt kaikkien oikeuksia yhdenvertaisesti - kuka jää tunnustamatta ja tunnistamatta, on ollut Kati Turtiaisen pitkäaikaisen kiinnostuksen kohde. Vuonna 2012 valmistuneessa väitöstutkimuksessaan hän tutki pakolaisten ja viranomaisten luottamussuhteita. Näiden teemojen pohdinta ohjasi hänet edelleen tarkastelemaan tunnustussuhteita ja sitä, miten ne toimivat viranomaisten ja pakolaisten välillä sekä toisaalta laajem- pina yhteiskunnallisina suhteina. Viime aikoina Turtiainen on pohtinut näitä kysymyksiä erityisesti paperittomiin siirtolaisiin ja muihin oikeudettomassa asemassa oleviin ihmisiin liittyen.

Tällä hetkellä Turtiainen työskentelee seitsemättä vuotta yliopistolehtorina Kokkolan yliopistokeskus Chydeniuksessa. Työssään hän on johtanut useita maahanmuuttoa ja pakolaisuutta käsitelleitä tutkimushankkeita. Näistä ensimmäinen keskittyi maahanmuuttajataustaisten perheiden varhaisen tuen tarpeisiin (ks. Turtiainen \& Hiitola 2015). Sitä seuranneessa EU Interreg -rahoitteisessa kehittämishankkeessa tarkastelun kohteena oli puolestaan pakolaisten vastaanotto pienillä maaseutumaisilla paikkakunnilla. Tutkimustyössään Turtiainen on keskittynyt järjestelmätason ilmiöihin. Hankkeissa kokoamiensa aineistojen pohjalta Turtiainen on kirjoittanut useita julkaisuja. Näistä viimeisin, yhdessä Tuomo Kokkosen kanssa laadittu artikkeli, käsittelee sitä, miten sosiaalityö asettuu suhteessa populismiin ja uusliberalismiin (Turtiainen \& Kokkonen 2020). 


\section{Pakolaistyön KehitTyminen KUNTIEN TEHTÄVÄNÄ}

Johanna: Kuinka aloitit urasi pakolaistyössä?

Ihan ensin olin mielenterveyspalveluissa sosiaalityöntekijänä. Työskentelin vuodesta 1984 alkaen Hesperian sairaalassa. Aika pian kuitenkin päädyin mukaan pakolaisten vastaanottoon. Jo 1980-luvun lopulla olin mukana suunnitteluryhmissä, joissa ryhdyttiin valmistelemaan kiintiöpakolaisten vastaanottoa Jyväskylään. Työskentelin silloin seurakunnan diakoniatyössä ja olin sitä kautta mukana Jyväskylässä kaupungin pakolaisia vastaanottavassa työryhmässä. Ensimmäisten pakolaisten saavuttua kuntaan tein työtä pääasiassa yhteisöjen kanssa. Konkreettisesti perustin työryhmän, joka koostui ihan tavallisista yhteisön jäsenistä. Mukana oli vapaaehtoisia suomalaistaustaisia ja vasta Jyväskylään tulleita pakolaisia. Se, mikä nyt palaakin mieleen on, että silloin oli aivan itsestään selvää, että ryhmässä täytyy olla myös pakolaisia mukana.Ajatuksena oli, että he itse tietävät parhaiten, mitä he tarvitsevat. On yllättävää, että tällä hetkellä käydään edelleen samoja keskusteluja.

Järjestimme työryhmän kanssa lähinnä infoiltoja, tutustumiskäyntejä ja leirejä. Nämä olivat palveluita, joita pakolaiset itse toivoivat, ja me järjestimme niitä tarpeen mukaan. Informaation jakaminen liittyi konkreettisiin arkielämän asioihin ja yhteiskuntatietoon. Usein asiakkaiden tarpeet liittyivät siihen, että haluttiin myös levätä hetki, kun elämä uudessa maassa ja uudella kielellä oli koko ajan niin vaativaa ja raskasta. Haluttiin viettää aikaa omalla kielellä ja tehdä yhdessä omaan kulttuuriin kuuluvia asioita. Asiakkaat itse suunnittelivat ison osan toiminnastaan. Aina oli kuitenkin mukana myös jotain uutta tietoa - koski se sitten kunnallista päätöksentekojärjestelmää tai jokamiehen oikeuksia.

Yksi keskeinen toiminto työssäni olivat vuosittaiset Lapin matkat yhdessä silloisen ulkomaalaistoimiston ja seurakunnan kanssa sekä luonnon antimien hyödyntäminen: kalastus, marjastus, sienestys. Mukana paikallisessa toiminnassa oli erilaisia järjestöjä, jotka järjestivät näitä mahdollisuuksia, kuten $4 \mathrm{H}$. Lapin matkoista tuli merkittävä työmuoto, ja niitä on järjestetty näihin päiviin saakka. Mukana ovat olleet myös maahanmuuttajapalveluiden sosiaalityöntekijä, sosiaalityöohjaaja ja/tai psykologi.

Toiminta kuitenkin vaihteli paljon 1990-luvun aikana riippuen siitä, millaisia ihmisiä Jyväskylään tuli ja minkälaisia yhteisöjä heistä muodostui. Tein paljon töitä esimerkiksi bosnialaisten Srebrenican verilöylyn jälkeen leiriltä tulleiden miesten kanssa. He olivat todella huonossa kunnossa. Perheenyhdistämiset tapahtuivat onneksi kuitenkin melko nopeasti - jos perheet vain olivat elossa. Tämä yhteisö on jäänyt vahvasti mieleeni, sillä heillä sodan ja pitkän keskitysleiritaustan jälkeiset traumat olivat todella syviä. Järjestimme miesten kanssa isojakin tapahtumia. Esimerkiksi yhdessä yhden bosnialaiseen yhteisöön kuuluvan miehen kanssa järjestimme pohjoismaisen tapahtuman, joka kokosi yhteen bosnialaisia myös Ruotsista ja Norjasta. Mukana oli norjalainen elokuvaohjaaja, joka oli tehnyt dokumenttielokuvan Bosniasta. Katsoimme kipeitä muistoja mieleen palauttavan elokuvan yhdessä. Tavan 
mukaan grillattiin myös lammasta ja juotiinkin, vaikka se ei olisi uskontoon kuulunutkaan. Yksi keskeinen funktio oli, että ihmiset saivat käydä läpi vaikeita asioita yhdessä omalla kielellään.

1990-luvun lopulla tein sosiaalityön maisterin tutkinnon loppuun, vaikka olin jo tehnyt sosiaalityön pätökoulutuksen aiemmin. Pätevöitymisen jälkeen jatkoin sosiaalityöntekijänä diakoniatyössä, vaikka en ollut erityisen uskonnollinen. 2000-luvun taitteessa olin vuoden opettajana ammattiopistossa, mikä on työurallani ainoa vaihe, jolloin en ole tehnyt maahanmuuttajatyötä. Vuonna 2003 aloitin Jyväskylän maahanmuuttajapalveluiden johtajana. Tunsin jo pitkän työkokemukseni perusteella paikalliset toimijat, koska verkostojen kanssa tehtävä tiivis yhteistyö oli ollut rutiinia ensimmäisten pakolaisten saapumisesta alkaen. Maahanmuuttajapalveluissa jatkoin työskentelyä samojen kohderyhmien kanssa, eli kiintiöpakolaisten, turvapaikan saaneiden ja inkerinsuomalaisten paluumuuttajien. Kehitimme edelleen ryhmä-, verkosto- ja yksilötyötä sekä myös yhteisöjen kanssa tehtävää työtä.

\section{Pakolaistaustaisten asiakkaiden SUURIMMAT HAASTEET}

Johanna: Mitkä olivat kokemustesi mukaan suurimpia haasteita asiakkaiden elämässä?

Asiakkaat reagoivat traumoihin kaikki hyvin eri tavoin. Nykytilanteeseen verrattuna suuri ero on, että aiemmin lähes kaikki perheenyhdistämiset onnistuivat ja vuosien odotusajat olivat harvinaisia. Juuri kenenkään ei tarvinnut käydä läpi sitä, että ydinperheen yhdistäminen ei onnistu. Tämä asia on nykyisin oleellisesti heikentynyt.

Vaikeiden traumaattisten kokemusten jälkeen yhdistyneillä perheillä oli isoja haasteita. Sekä Suomeen tulleilla että heidän perheillään oli usein vaikeita kokemuksia takanaan. Nämä kokemukset tuottivat uusia jaksamiseen liittyviä ongelmia, mutta eivät tietenkään kaikille. Tänä päivänä voidaan ajatella, että selviytymisessä näkyivät yksilökohtainen resilienssi ja vastaanottavan yhteisön valmiudet. Minua onkin aina kiinnostanut, kuinka jotkut selviävät niin hyvin ja toisilla on hyvin vaikeaa. Kaikki eivät jatkaneet elämäänsä perheenyhdistämisen jälkeen yhdessä perheensä kanssa. Monille tuli myös avioeroja. Selviämisessä oli keskeistä se, että asiakas osasi ja halusi hakea vaikeuksiinsa apua ja että oikeanlaista apua ylipäätänsä oli olemassa.

Sotien aikana syntyy myös isoja perhetragedioita, joita kaikki eivät kestä. Esimerkiksi, kun naisia raiskataan, kaikilla lapsilla ei välttämättä ole sama isä. Lapsia myös kootaan yhteen, kun vanhempia kuolee tai häviää, ja monet ottavat läheisiä lapsia hoidettavakseen. Lapsia tavallaan adoptoidaan, mutta sotatilanteessa papereita ei ole. Näitä perhetilanteita ja tragedioita eivät valitettavasti Suomen nykypolitiikka ja erityisesti tiukentunut perheenyhdistämislainsäädäntö tunnista. Tilanteet ovat vaikeita puolin ja toisin. Vaikeaa on sijaisvanhemmilla, jotka kokevat velvollisuudekseen huolehtia vanhempansa menettäneistä lapsista, mutta eivät sitten turvapaikan saatuaan saakaan pitää sosiaalisia lapsiaan. Lisäksi vaikeaa on tietysti lapsilla, joiden huolenpitosuhteet jäävät ratkaisematta. Sosiaali- 
työssä on keskeistä ymmärtää, etteivät sotatilanteessa eläneiden ihmisten viralliset paperit kerro arjen todellisuudesta. Keskeisiä ovat tosiasialliset hoiva- ja huolenpitosuhteet. Perheet ovat syntyneet jossain kohtaa todellisista tarpeista. Toki on ymmärrettävää, että maahanmuuttolainsäädäntö määrittelee, ettei yhdellä perheellä voi olla loputonta määrää lapsia. Tämänhetkisessä maahanmuuttopolitiikassa täydellisen riippuvuuden määritelmää ei kuitenkaan ole käytetty siinä määrin kuin sitä voitaisiin käyttää.

Inkerinsuomalaisten kanssa tein todella pitkään töitä. Heidän paluumuuttonsa oli 15 vuotta kestänyt vaihe. Työntekijänä kannustin ja ohjasin muun muassa vapaaehtoisia. He olivat "Siperiat kulkeneet" ja kokeneet paljon menetyksiä sekä vaikeita traumoja. Inkerinsuomalaiset olivat todellisia selviytyjiä elämässään, ja opin heiltä paljon. Esimerkiksi ikääntynyt ihminen saattoi tulla pienen kassin kanssa Pietarista bussilla Jyväskylään tietämättä, mihin linja-autoasemalta suunnistaa. Hän oli saanut konsulaatista luvan tulla Suomeen, mutta paluumuuton alkuvuosina Suomessa ei tarvinnut olla vielä asuntoa ennen muuttoa. Inkerinsuomalaisilla oli valtava luottamus siihen, että he selviytyvät ja että ihmiset auttavat heitä.

\section{HYVIÄ KÄYTÄNTÖJÄ JA TOIMIVIA TYÖTAPOJA PAKOLAISTYÖSSÄ}

Johanna: Millaisia työtapoja olet vuosien varrella kehittänyt pakolaisten kanssa tehtävässä työssä?

Työssä on keskeistä yhteiskuntaan, oikeuksiin ja palvelujärjestelmään pereh- dyttäminen sekä paikan raivaaminen lähiyhteisöissä. Laadukkaan työn perusta on psykososiaalisessa yksilötyössä. Tarve tälle on nähty jo kauan. Tämän takia maahanmuuttajapalveluiden sosiaalityötä ja sosiaaliohjausta täydentämään tuli meille Jyväskylään psykologi jo 2000-luvun alussa. Psykologi teki tukea antavaa terapiaa. Hänen avustuksellaan ihmiset saatiin eteenpäin tarvittaviin muihin terapioihin ja psykiatrisiin palveluihin. Psykologin rooli oli myös normalisoida palveluita, pitää tiedotustilaisuuksia ja ohjata ryhmiä. Tällainen moniammatillinen kokonaisvaltaisuus on merkittävää vastaanottotyössä, sillä se oikea-aikaistaa tarvittavia tukitoimia. Erityisesti mielenterveyspalveluihin pääsyyn on sosiaalityössä syytä kiinnittää huomiota, koska traumatausta voi olla hyvinvoinnin esteenä ja siirtyä sukupolvelta toiselle. Maahanmuuttajapalveluissa meillä oli myös yhteistyötä kidutettujen kuntoutuskeskuksen kanssa. Meidän roolimme oli motivoida ihmisiä hoitamaan traumojaan.

Jo 1990-luvun alusta lähtien kehitin erityisesti ryhmämuotoista naisten kanssa tehtävää työtä. Esimerkiksi bosnialaisten, iranilaisten ja kurdien kanssa pidimme ryhmiä.Yhdessä aina suunnittelimme, mitä he haluavat tehdä. Iso osa työstä oli surua ja suremista sekä uuteen tilanteeseen sopeutumista. Joskus oli traumojen läpikäymistä ryhmissä, jolloin työparinani oli psykologi. Itsellänikin on pitkä kriisi- ja traumatyön koulutus, joten tällainen työ on ollut luontevaa.

Yksi mieleen jäänyt ryhmä ovat irakilaiset miehet, joiden salakuljettajien laiva oli kaatunut matkalla Indonesiasta Australiaan. Monien perheenjäsenet 
olivat hukkuneet, ja miehet olivat jääneet yksin.YK neuvotteli nämä miehet pakolaiskiintiön mukana Suomeen. He siis olivat aiemmin pitkään eläneet Iranissa ja pyrkineet tuolla kaatuneella laivalla pakolaisiksi Australiaan. Näiden perheensä menettäneiden miesten kanssa ryhmätapaamiset olivat yksi keskeinen työmenetelmä. Yleensäkin vertaistuella ja omasta yhteisöstä tulevilla "menestyskertomuksilla" on iso rooli pakolaistaustaisten asiakkaiden kanssa tehtävässä työssä.

Näin maahanmuuttajapalveluiden johtajan yhtenä tehtävänä työn laadun kehittämisen. Tein tätä työtä pienissä kehittämishankkeissa, joissa oli aina vähintään osa henkilöstöstä mukana. Se oli oman toimiston työn kehittämistä. Lähes koko ajan meillä oli joku pienimuotoinen Euroopan pakolaisrahaston hanke, esimerkkinä vuosia kestänyt lapsia ja nuoria koskeva hanke, jossa keskeistä oli pakolaistaustaisten lasten koulumotivaation ylläpitäminen. Mukana oli myös yliopiston opettajaopiskelijoita, ammattikorkeakoulun sosionomiopiskelijoita ja aineopettajia tekemässä harjoitteluja.

Yksi tärkeä ja erittäin opettavainen hanke kohdistui naisten raiskaustraumoihin. Saimme hankerahoituksen kongolaisten pakolaisnaisten tukemisen kehittämiseen yhdessä Tukinaisen kanssa. Hankkeen oppi oli yllättävä. Ajattelimme Tukinaisessakin toimineiden pienryhmien olevan naisille sopiva hoitomuoto. Hankkeessa kävi kuitenkin niin, että ryhmämuotoinen tukeva terapia ei toiminut. Naiset eivät missään nimessä halunneet puhua ryhmässä, vaan halusivat toimia yhdessä ja tehdä yhdessä ihan muita asioita. He kaikki tiesivät toistensa taustat ja jakoivat saman kokemuksen, mutta he eivät halunneet puhua siitä yhdessä. Tämä on minua syvästi koskettanut asia: se, että voi jakaa asioita vain tietämällä toisen taustoista mutta olemalla hiljaa yhdessä, ihan muita asioita tehden. Naiset kuitenkin halusivat puhua yksilöterapiassa. Meillä oli lisäksi mukana yksi kongolaistaustainen nainen kokemusasiantuntijana. Hankkeen puitteissa kiersimme eri paikkakunnilla puhumassa sota-alueilla tapatuvasta seksuaalisesta väkivallasta ja raiskaustraumoista. Muita mieleen jääneitä hankkeita oli esimerkiksi "Maahanmuuttajamummola", jonne yksinhuoltajaäidit voivat mennä mummolaan yhdessä lastensa kanssa. Hanke jäi pieneksi, mutta perheille siitä jäi elinikäiset mummolat.

\section{Pakolaisten valintamatkoilla}

Johanna: Olet ollut mukana myös valitsemassa Suomen kiintiöpakolaisia leireiltä. Lukijoita varmasti kiinnostaisi kuulla vähän näistä kokemuksista. Miten päädyit valintamatkoille mukaan?

Kuntien kotouttamistyötä tekevien tapaamisissa puhuimme tuolloin valintamatkoista vastuussa olleen työ- ja elinkeinoministeriön kanssa. Nähtiin, että kuntien työntekijät hyötyisivät valintamatkoista ja kotouttamistyötekijöillä voisi olla myös tarjottavaa. Aiemmin käytäntönä oli, että asiakkaat vain ilmestyivät kuntiin ilman, että heistä tiedettiin juuri mitään. Ylitarkastaja Sirkku Päivärinne tarttui asiaan, ja ministeriö päätti ottaa kuntien edustajia mukaan prosessiin jo pakolaisten valintavaiheessa ministeriön ja SUPO:n lisäksi. Kuntien ja ELY-keskusten edusta- 
jia on ollut sittemmin valintamatkoilla mukana niin kutsuttuina kotoutumisen asiantuntijoina. Ensimmäinen matkani oli vuonna 2006, jolloin valitsimme burmalaisia Pohjois-Thaimaasta pakolaisleiriltä. Seuraava matka vuonna 2008 suuntautui Ruandaan, jossa valitsimme kongolaisia pakolaisia. Sitten kävin Egyptissä valitsemassa sudanilaisia pakolaisia vuonna 2013.

Näitä valintamatkoja ennen, jo 15 vuotta sitten, olin mukana hankkeessa, jossa mallinnettiin globaaliin pohjoiseen tulevien pakolaisten vastaanottoa ja tehtiin EU:1le suosituksia. Siinä vaiheessa kävimme tutustumassa Keniassa Dadaabin pakolaisleiriin, joka oli Somalian rajalla. Matka oli todella silmïa avaava. Tutustuimme eri järjestöihin Keniassa, ja tuolloin ymmärsin, miten paljon suojelun tarpeessa olevia pakolaisia jää leirien ulkopuolelle ja virallisten tilastojen katveeseen. Ihmisten pakotettu muutto on valtava ratkaisematon globaali ongelma.

Valintamatkoilla valitsimme Suomen linjausten mukaisesti kaikista haavoittuvimmat henkilöt. Kysymys siitä, kuka on haavoittuvimmassa asemassa, ei ole yksinkertainen tai selkeästi ratkaistavissa.Yksi hankaluus on se, että jos valintamatkalla ajatellaan jonkun olevan niin heikossa tilanteessa, ettei hän voisi kotoutua Suomeen, ei valintaa välttämättä tehdä. Esimerkkinä ovat vaikkapa vaikeat päihde- tai mielenterveysongelmat. Näin ollen ei voida sanoa, että valinnat aina kohdistuivat kaikista haavoittuvimpiin. Kunnan työtä seuranneena tilanne on absurdikin. Ennalta ei voida nimittäin tietää, kuka "kotoutuu". Henkilö, josta leirillä ajattelee, että hän varmasti sopeutuu Suomeen todella hyvin, voi- kin sitten kohdata valtavia vaikeuksia Esimerkiksi hyvin kouluttautunut mies saattaakin jäädä työmarkkinoilla tapahtuvan syrjinnän vuoksi Suomessa pitkäaikaistyöttömäksi eikä saa ollenkaan niin hyvin yhteiskunnasta kiinni kuin vaikkapa luku- ja kirjoitustaidoton nuori nainen.

Lopulta sen päättäminen, kuka on heikossa asemassa ja kuka ei, on todella vaikeaa. Kunnassa tuli nimittäin usein vastaan se, että vaikka joku oli leirillä todella huonossa kunnossa, hän saattoikin sitten kunnassa olla se resurssihenkilö. Resilienssiä ja voimavaroja ei heti näe, se on usein yllätys. Ihmisten kykyä toipua ja asettua yhteiskunnan osaksi ei voida ennalta tietää. Usein kotoutuminen rikkoo stereotypioita.

Leireillä suhteellisuuden taju avautuu aivan uudella tavalla. Tämä yhdistyykin ajatuksissani huoleen tästä päivästä, jolloin niin valtava määrä ihmisiä on pitkittyneessä pakolaistilanteessa, jopa sukupolvesta toiseen. Ihmiset, jotka eivät halua jäädä leirille odottamaan ja ovat kuulleet onnistumisista, lähtevät itse toimimaan. Monet kuolevat matkalla. Lisäksi tämä nykyjärjestelmä, kansainvälinen yhteisö, kohtelee kaltoin. Jos joku yksilö yrittää toimia siten, ettei hänelle tulisi sukupolvia kestävää odottamista, häntä vastassa ovatkin yksittäisten kansallisvaltioiden intressit rajoittaa maahanmuuttoa. Tämä on iso kansainvälisen yhteisön epäjohdonmukaisuus. Ihmisten, jotka elävät toisessa tai kolmannessa sukupolvessa pakolaisleirillä, pitäisi päästä sieltä pois. Voidaan kysyä, miksi he sitten eivät saisi hakea turvapaikkaa esimerkiksi Euroopasta, jos omalle ja perheen tulevaisuudelle ei ole mitään 
näkymiä. Tilanne on muuttunut: aikaisemmin vastaavissa olosuhteissa eläneet ovat saaneet turvapaikkoja, mutta tänä päivänä he eivät niitä enää saa. Poliittiset muutokset näkyvät suoraan vastaanottotyössä, joka läpileikkaa todella monia yhteiskunnallisia ja globaaleja kysymyksiä.

\section{MuUTtuva VASTAANOTTOTYÖ}

Johanna: Kerrotko vielä meille vähän, kuinka pakolaisten vastaanottotyö muuttui sinun työvuosiesi aikana.

Yksi iso muutos liittyy projektien kasvavaan merkitykseen monikulttuurisessa työssä. Monen projektin käytännöt eivät kuitenkaan ole jääneet elämään, mikäli ne eivät ole pohjautuneet joko olemassa olevan työn kehittämiseen tai juurtuneet verkostoihin. Jyväskylän kokoisessa kaupungissa toimijoiden määrä oli 2000-luvun alussa vielä hallittava. Tällöin yhteistyö ja työn koordinointi toimivat. Tiedän, että tilanne on nyt muuttunut ja erityisesti laajempaan monikulttuurisuuteen liittyviä hankkeita on paljon, eikä niiden välillä tai kunnan työn ja hankkeiden välillä ole riittävää koordinointia. Näin olen kuullut nykyisiltä toimijoilta.

Asiakkaiden tilanteissa suurimmat muutokset liittyvät myös lakimuutoksiin. Esimerkiksi heti, kun perheenyhdistämiseen liittyvä laki heikentyi vuonna 2010 ja vielä uudelleen 2011, huomasimme muutoksen vastaanottotyössä. Ihmisten asettuminen Suomeen hankaloitui. Positiivinen muutos puolestaan liittyi aikoinaan kotolakiin. Sen seurauksena ryhdyttiin asiakkaille tekemään kotosuunnitelmat. Siinä kohtaan yhteistyö TE-toimiston kanssa muuttui aiempaa tiiviimmäksi. Näitä kotosuunnitelmia on Jyväskylässä sittemmin tehty yhdessä.

Yksi muutos on työntekijöiden koulutuksen lisääntyminen. Kotoutumiskoulutus on myös moninaistunut vuosien mittaan. Myös yhteistyö kotokouluttajien, päiväkotien, perusopetuksen ja muiden oppilaitosten kanssa on organisoitunut kunnissa uudella tavalla. Jyväskylässä meillä oli eri palveluissa yhteyshenkilöt, jotka olivat myös mukana laatimassa kunnan kotouttamisohjelmaa. Työ muuttui epävirallisista verkostoista suunnitelmallisemmaksi; tästä esimerkkinä se, että päiväkotien varhaiskasvatussuunnitelmiin liitettiin kotoutumissuunnitelmat. Perheiden ei tarvinnut laatia useita suunnitelmia vaan suunnitelmat mukailivat lapsen arkea.

Osaamisen lisääntyminen on näkynyt myös terveydenhuollossa. Meillä oli esimerkiksi Jyväskylässä pieni projekti, jossa terveysasemille perehdytettiin vastuuhoitajia, jotka tekivät pakolaisten alkutarkastuksia. Huomattiin myös, että usein "kaikki tekee kaikkea" -malli ei toiminut vaan siitä tuli "kukaan ei tee kunnolla” -periaate. Monissa palveluissa päädyttiin osaamisen keskittämiseen työyhteisöissä ja nämä työyhteisön resurssihenkilöt toimivat parhaimmillaan osaamisresurssina työtovereilleen.

Työprosesseja kehitettiin jo 1990-luvun alusta lähtien. Kun kotoaika määrittyi kolmeksi vuodeksi, henkilöstömäärä kasvoi vastaanottavassa työssä. Osa asiakkaista ei kuitenkaan tarvinnut kolmea vuotta, ja osalle se ei taas riittänyt. Varsinkin, jos perheenyhdistämi- 
set olivat kesken, asiakkaan voimavarat eivät riittäneet kotoutumiseen. Iso muutos asiakkaiden elämässä oli myös se, että etniset ja uskonnolliset yhteisöt kasvoivat. Maahanmuuttajat perustivat itse yhdistyksiä, ja näistä oli asiakkaille tukea. Tietysti joskus ratkottiin myös konflikteja, mutta tilanne selvästikin muuttui yhteisöjen kasvamisen myötä.

Nykytilanteesta nostaisin esiin myös rasismin nousun, mihin myös poliittiset päätökset oleskelulupien myöntämisen kiristymisestä liittyvät. Yhteiskunta on uudella tavalla polarisoitunut, ja tämä näkyy asiakkaiden arjessa. Kaikkien meidän olisi tärkeää tunnistaa populismi ja siihen liittyvä monimuotoisuuden hyväksymättömyys. On helppoa tuudittautua poliittiseen retoriikkaan. Kovin helposti sosiaalityössäkin voidaan alkaa puhua populismin äänellä "rajoista". Se on asiakkaille haavoittava kokemus ja tärkeä sosiaalityössä tiedostettava asia.

\section{TÄRKEITÄ OPPEJA UUSILLE SOSIAALITYÖNTEKIJÖILLE}

Johanna: Mitkä ovat tärkeimpiä oppeja, joita haluaisit välittää unsille pakolaisten kanssa tehtävää työtä aloittaville työntekijöille?

Yksi keskeinen asia on, että asettuminen uudessa yhteiskunnassa ei tapahdu vain sinne, mihin on tultu, vaan myös niihin muihin paikkoihin, joissa on sukua sekä lähtömaahan. Asettuminen ja siten kotoutuminenkin on monipaikkaista. Tästä tullaan ylirajaisen työn välttämättömyyteen. Tätä olemme painottaneet uusimmassa kirjassamme, jonka toimitin yhdessä Johanna Hiitolan, Sabine Gruberin ja Marja
Tiilikaisen (2020) kanssa. Ylirajaisuuteen liittyvät traumaattiset kokemukset mutta myös läheissuhteet. Jos asiakkaan omassa maassa on sota tai konflikti ja perheenyhdistäminen ei toteudu, tai jos perheenjäseniä on kateissa, niin mieli ei voi asettua. Huoli on silloin päällimmäisenä eikä kotoutuminen ole samanlaista. Tosin ihmisten resilienssi on hyvin yksilöllistä.

Monipaikkaisuus mahdollistuu myös kommunikaatioteknologioiden kehittymisen myötä. Ihmiset pystyvät pitämään perhe-elämää yllä aktiivisestikin uusien välineiden avulla. Tätä pitäisi vielä enemmän hyödyntää vastaanottovaiheessa. Miten voisimme olla tekemisissä myös sen ylirajaisen perheen kanssa tai ymmärtää, että asiakkaamme etsivät turvaa myös yhteisöltään tai perheenjäseniltään? Näiden suhteiden hyödyntäminen antaisi uusia mahdollisuuksia työhön. Kehottaisin kaikkia sosiaalityöntekijöitä rohkeasti kokeilemaan uusia työtapoja.

Yksi tärkeä asia, jolla päästään jo pitkälle, on, että sosiaalityön perusopit ja eettiset periaatteet sekä vuorovaikutustaidot otetaan tosissaan. Näen "kulttuurisensitiivisyydenkin" kysymisen taitona, jossa tarvitaan ymmärrystä ilmiöistä eikä niinkään "kulttuureista". Ylipäänsä kulttuureista tietäminen on aika mahdotonta, koska kaikilla on oma tarinansa. Oleellista on tieto esimerkiksi siitä, mitä pakolaisprosessissa saattaa tapahtua, mitä traumat voivat aiheuttaa, mitä tapahtuu hauraissa valtioissa ja sodassa elävissä yhteiskunnissa tai millaisia jälkiä nämä asiat saattavat jättää. Miten sota murentaa käsitystä itsestä ja luottamusta järjestelmään? Mitä sota tekee vaikka käsitykselle perheestä, parisuh- 
teesta ja kasvattamisesta? Kaikki nämä selviävät vain asiakkailta kysymällä. Vuorovaikutustaidot ovat tärkeimpiä. Niitä ei voida liikaa korostaa. Myös yhdessä Johanna Hiitolan ja Merja Aniksen (2018) kanssa toimittamamme kirja keskittyy tähän yksilöllisen kohtaamisen tarpeeseen.

Työssä on tärkeää olla asiakkaan puolella, vaikka asioita ei voisi aina kääntää parhain päin. Miten sille samalle puolelle sitten päästään? Tässäkin tärkeää on kysyminen ja sen osoittaminen, että haluaa ymmärtää, vaikka ei aina ymmärrä. Tämähän ei tarkoita vain sitä, että on kiltti ja mukava, vaan työssä joutuu käymään vaikeitakin keskusteluja. Siinä tulee myös työntekijän oma resilienssi esiin. Lisäksi työntekijän on keskeistä ymmärtää, miten kriisissä oleva ihminen käyttäytyy.

Sosiaalityöntekijyys ei suojaa siltä, että alkaakin työssään toteuttaa institutionaalista syrjintää. Tarvitaan paluuta antirasistisen työn juurille ja täytyy tunnistaa valtasuhteita. Tässä kohtaa voin kyllä sanoa, että valitettavasti tämä monikulttuurinen sosiaalityö ei ole valtavirtaistunut. Eri puolilla Suomea on hyvin erilaisia tilanteita ja osaamista. Johtavien sosiaalityöntekijöiden merkitys on aivan valtava. Palasi mieleeni joitain vuosia sitten tekemämme maahanmuuttajataustaisten perheiden varhaisen tuen selvitys (Turtiainen \& Hiitola 2015). Selvityksessä näkyi, että ne alueet, joissa ei ollut johdon tukea, olivat myös niitä, joissa oli eniten syrjiviä käytäntöjä.

Nyt, kun muistoissani olen palannut 1990-luvulle, olen jopa hätkähtänyt, kuinka edistyksellistä työtä me jo silloin teimme. Sitä työtä ei soisi unohdettavan.

\section{KirJallisuUs}

Hiitola, Johanna \& Anis, Merja \& Turtiainen, Kati (toim.) (2018) Maahanmuutto, palvelut ja hyvinvointi. Kohtaamisissa kehittyviä käytäntöjä.Tampere:Vastapaino.

Hiitola, Johanna \& Turtiainen, Kati \& Gruber, Sabine \& Tiilikainen, Marja (toim.) (2020) Family life in transition: Borders, transnational mobility and welfare society in Nordic countries. London: Routledge. https:// doi.org/10.4324/9780429024832

Turtiainen, Kati \& Hiitola, Johanna (2015) Varhaisen tuen palvelut maahanmuuttajataustaisille perheille. Ammattilaisten ja vanhempien kokemuksia. Julkaisuja 68 . Helsinki:Työ- ja elinkeinoministeriö.

Turtiainen, Kati \& Kokkonen, Tuomo (2020) Citizenship, populism and social work in the Finnish welfare state. Teoksessa Carolyn Noble \& Goetz Ottmann (toim.) The Challenge of Right-wing Nationalist Populism for Social Work - A Human Rights Approach. London: Routledge. https://doi. org/10.4324/9780429056536-10 